\title{
Myrothecium as Promising Model for Biotechnological Applications, Potentials and Challenges
}

\author{
Waill A Elkhateeb and Ghoson M Daba* \\ Department of Chemistry of Microbial Natural Products, Egypt
}

*Corresponding author: Ghoson Mosbah Daba, Department of Chemistry of Microbial Natural Products, National Research Centre,

Tahrir Street, 12311, Dokki, Giza, Egypt

\section{ARTICLE INFO}

Received: March 22, 2019

Published: March 28, 2019

Citation: Waill A Elkhateeb, Ghoson M Daba. Myrothecium as Promising Model for Biotechnological Applications, Potentials and Challenges. Biomed J Sci \& Tech Res 16(3)-2019. BJSTR. MS.ID.002869.

\begin{abstract}
Myrothecium is a fungal genus that belongs to family Stachybotryaceae and has been involved as promising tool in many important mycotechnological applications such as potent bioherbicides with strong virulence against wide range of weeds and harmful plants from different plant families. Furthermore, Myrothecium exhibited strong insecticidal activities especially against mosquitoes and nematodes among other insects, promising antimicrobial activities, Myrothecium species are involved in many biotechnological applications due to secondary metabolites produced by them, and this review discuss challenges and potentials concerning using this genus as a tool in some medicinal and biotechnological applications.
\end{abstract}

Keywords: Myrothecium; Biological Control; Biotechnology; Secondary Metabolites

\section{Introduction}

Myrothecium species have a worldwide distribution as endophytic fungi that colonize various hosts [1], as saprophytic fungi in the soil and decaying tissues of plants [2-4], or as pathogens on various hosts [5-9]. Myrothecium species belong to the fungal family Stachybotryaceae, and over 30 species have been reported till 2011 [10], while the Index Fungorum database listed 90 records for Myrothecium in March 2019 http://www.indexfungorum. org/names/Names.asp. In this review, the biological activities, potential biotechnological applications, and challenges facing commercializing Myrothecium or its products were highlighted in order to encourage more studies on this miraculous fungus.

\section{Myrothecium as Source of Biologically Active Compounds}

Myrothecium species are prolific producers of vast of biologically active secondary metabolites such as enzymes, antibiotics, sesquiterpenoids, triterpenes, diterpenoids, cyclopeptides such as verrucamides A-D [11-15]. Additionally, Myrothecium species produce many macrocyclic trichothecene mycotoxins such as verrucarins and roridins, [16-18]. More than twenty compounds were reported from $M$. roridum, and arround thirty compounds were listed to be originated from M. verrucaria [19]. Some Myrothecium species, such as M. verrucaria, are known for their production of many enzymes such as lipases, chitinases, laccases, and proteinases $[20,21]$. The chemical structures of some trichothecene mycotoxins produced by Myrothecium species were illustrated in Figures $1 \& 2$.

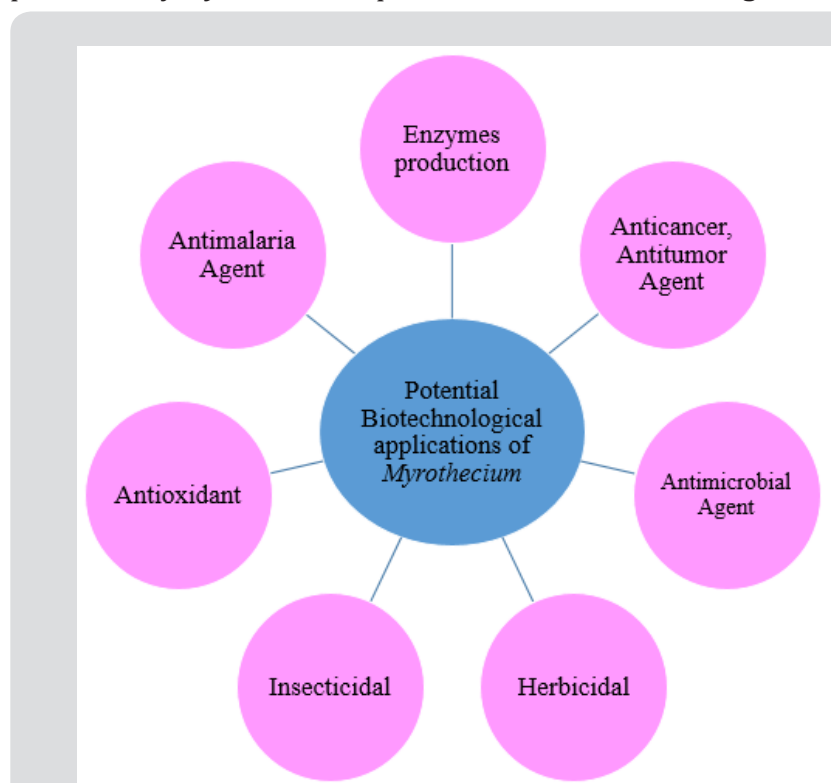

Figure 1: Some biotechnological applications of Myrothecium. 


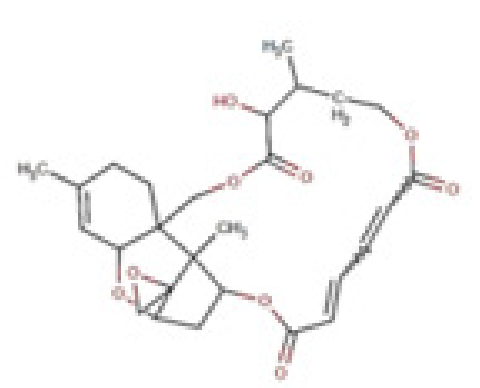

Verrucarin A

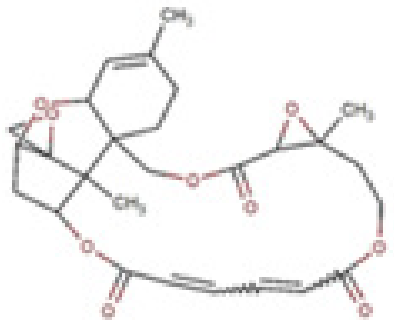

Verrucarin B

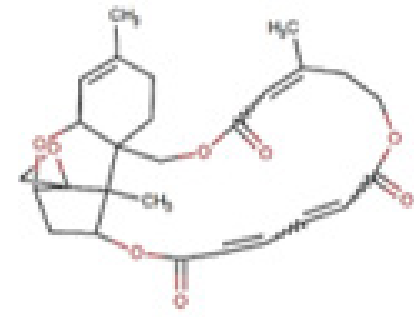

Verrucarin J

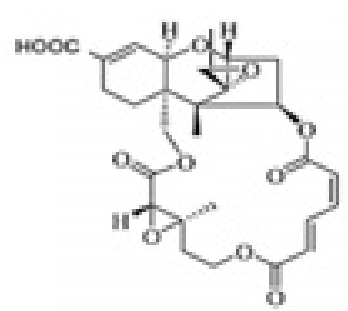

Verrucarin Z

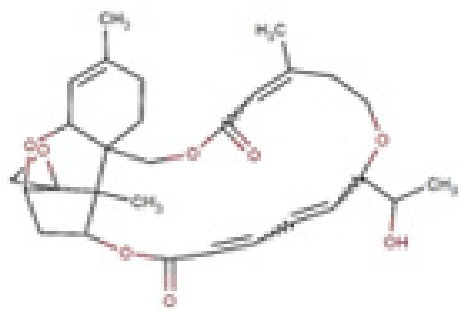

Roridin E

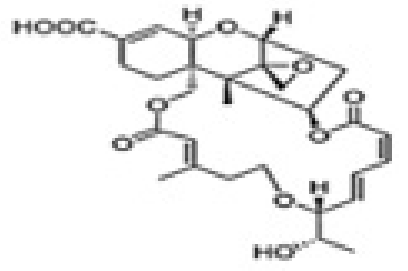

Epiroridin acid

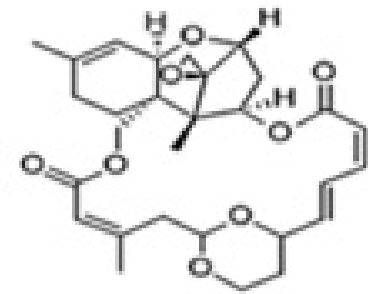

Roridin $\mathrm{H}$

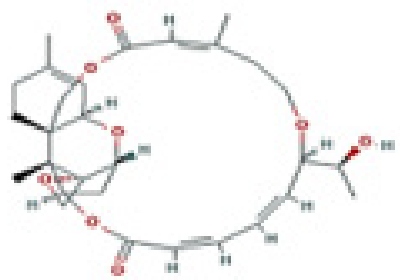

Epiroridin E

Figure 2: Chemical structures of some biologically active trichothecenes mycotoxins.

\section{Some Biotechnological Applications of Myrothecium}

\section{Myrothecium uses in Biocontrol of Insects}

Thanks to its ability to produce many enzymes, Myrothecium verrucaria has a promising insecticidal activity. Those produced enzymes are capable of degrading the extracellular cuticles of insects $[20,22,23]$. Thus, M. verrucaria represents potential tool for the biocontrol of insects such as mosquitoes [22]. Moreover, the activity of $M$. verrucaria as a nematophagous fungus could be used in bio- controlling losses in crops from nematodes. Different mechanisms of nematodes inhibition by $M$. verrucaria were previously reported, those include affecting hatching of egg, inhibiting development, or through killing the nematode itself $[24,25]$.

\section{Myrothecium Herbicidal Spectrum and Uses}

Using synthetic herbicides in natural habitats is not recommended due to its impacts on surrounding ecological systems, and the risk of affecting other plants due to the close association 
between harmful plants (targeted to be killed), and the plant to be protected. Hence, using bio-herbicides may offer alternatives to the control of weeds with synthetic compounds including the use of plant pathogens as bioherbicides [26]. Myrothecium verrucaria is known as for its virulence against numerous weed plant species and is potentially useful as a bio-herbicide [27]. Spraying crude extract preparations of $M$. verrucaria has proven its pathogenicity against different exotic plants and weed species belonging to different plant families [9] such as plumeless thistle (Carduus acanthoides L.) [28]; leafy spurge (Euphorbia esula L.) [29]; sicklepod (Cassia obtusifolia L.) $[27,30]$; hemp sesbania [Sesbania exaltata Rydb. ex. A.W. Hill] [27]: kudzu [Puereria lobata (WilId.) Ohwi] [31,32], many weeds affecting commercial tomato fields such as common purslane, horse purslane, spotted spurge, and prostrate spurge [26], besides many morning-glory species (Ipomoea spp.) [33].

Furthermore, $M$. verrucaria present a promising bioherbicide for controlling pre-plant weed [26]. In spite of having desirable bioherbicidal characteristics such as its high virulence capabilities and broad weed host range, there is a serious disadvantage standing in front of commercializing Myrothecium traits, which is production of mycotoxins such as the macrocyclic trichothecenes $[31,34]$. Studies are now trying to reduce or those mycotoxins $[12,35]$. Approaches conducted to solve such problem include changing Carbon and nitrogen sources and concentrations within the culture media [35], getting rid of spores by washing [35], and preventing spore production during growth of the fungus within the liquid culture medium [36].

\section{Myrothecium Production of Bilirubin Oxidase}

Myrothecium verrucaria has been known as a producer of bilirubin oxidase [37-39], which has various biotechnological applications such as manufacturing biobatteries and biosensors, bleaching of clothes, degradation of effluents, and dye decolorization [40-43].

\section{Myrothecium Antimicrobial Activities}

The antibacterial activity of Myrothecium crude extracts has been previously reported against wide range of pathogenic bacteria such as Escherichia coli, Salmonella Typhi, Klebsiella pneumoniae and Bacillus cereus [44, 45]. A study by Ruma et al. [46] revealed promising antibacterial activities against Bacillus subtillis, Klebsiella pneumoniae, Shigella flexneri, while moderate activities were recorded against Staphylococcus aureus, Escherichia coli, and Salmonella typhi [46]. The cyclic tetradecapeptides, verrucamides A-D were responsible for antibacterial activity againstStaphylococcus aureus [14], whereas some quinone sesquiterpenes were reported to exhibit activity against Staphylococcus aureus and Bacillus cereus [47]. An extract of Myrothecium verrucaria fermentation culture containing the cyclopeptides Verrucamides A-D, showed promising antibacterial activity against Staphylococcus aureus $[9,14]$. On the other hand, many fungi showed susceptibility to Myrothecium crude extracts such as Sclerotinia sclerotiorum [48]; Candida albicans [46]. A novel triterpene glycoside named FR227244 exhibits in vitro antifungal activity against Aspergillus sp., Trichophyton sp., Candida utilis, and Candida parapsilosis [49].

\section{Other Biological Activities Exerted by Myrothecium Species}

Ruma et al. [46] have reported the antioxidant activity of some Myrothecium species crude extracts when assessed by DPPH and ABTS radical scavenging methods. Extracts of some Myrothecium Species exhibited protection of DNA at a concentration of $50 \mathrm{mg} /$ $\mathrm{mL}$ [46]. The macrocyclic trichothecene mycotoxins verrucarin $\mathrm{A}$, verrucarin $\mathrm{J}$, roridin $\mathrm{A}$, and roridin $\mathrm{E}$ isolated from the freeze-dried culture filtrate of $M$. verrucaria BCC 112 exerted strong antimalarial activity against Plasmodium falciparum (K1 strain) [50]. The diterpene antibiotic, myrocin $\mathrm{C}$, exhibited an antitumor activity that moderately increased the life span of Ehrlich ascites tumorbearing mice [51]. Myrothecium spp. have been investigated for the management of cancer due to cytotoxic impacts [52]. Myrothecium species showed also ability to fight some tumours and inhibit liver cancer [53]. The list of potential applications of Myrothecium itself or compounds originated from Myrothecium is steadily increasing. Some potential biotechnological applications of Myrothecium is illustrated in Figure 1.

\section{Harmful sides of Myrothecium}

Generally, Myrothecium species are commonly found in the environment as endophytes and/or saprophytes on dead and decaying plant tissue [54,55], except for some species such as the famous plant pathogen Myrothecium roridum Tode [56], and the weak pathogen M. verrucaria Ditmar [8]. The development of plant diseases caused by Myrothecium is generally related to wet soil conditions, that's why it is important to take care of watering and soil sanitation in order to reduce crops losses [57]. Myrothecium species have been reported previously infecting coffee [58], seeds of rice and soybean [59], mulberry [52,60], chilli seed [61], rubber fig (Ficus elastic) [62]. Moreover, species Myrothecium were found infecting different economically important crops such as causing leaf blight in cotton [63], Peanut [4]; root rot in red clover [64], leaf spot in sunflower [65], potato [66], and leaf spot pepper [67].

Although the observed phyto-pathogenicity of some $M y$ rothecium species may cause threaten to some crops, especially economically important crops, but it can be directed toward the field of biological control. On the other hand, some species of Myrothecium were reported as indoor air contaminant or growing inside houses which represent potential health hazard due to their ability to produce mycotoxins [68]. Nevertheless, no study has evaluated Myrothecium risk to humans [68]. Myrothecium species produce many mycotoxins such as roridins produced by both M. roridum and M. verrucaria. Roridins are lethal to some plants even in very small concentrations, and they cause myrotheciotoxicosis, sudden death in cattle and sheep accompanied with pulmonary congestion and edema, in addition to necropsy lesions 
of abomasitis, hepatitis [69-75]. However, many of these trichothecenes mycotoxins exhibited promising biological activities as shown in Table 1. The chemical structure of these trichothecenes mycotoxins were illustrated in Figure 2.

Table 1: Some biologically active trichothecenes mycotoxins.

\begin{tabular}{|c|c|c|}
\hline Mycotoxin & Application & Reference \\
\hline Roridin A & Antimalarial agent & Isaka et al. [50] \\
\hline & Nematicidal activity & Nguyen et al. [70] \\
\hline Roridin E & Antimalarial agent & Isaka et al. [50] \\
\hline Roridin H & Phytotoxic, and cytotoxic to mammalian cell lines & Lbbas et al. [31] \\
\hline \multirow{2}{*}{ Verrucarin A } & Inhibits proliferation and induces apoptosis in prostate cancer cells by inhibiting prosurvival [71] \\
\cline { 2 - 4 } & Akt/NF-kB/mTOR signaling. & Isaka et al. [50] \\
\hline Verrucarin B & Antimalarial agent & Nguyen et al. [70] \\
\hline \multirow{2}{*}{ Verrucarin J } & Nematicidal activity & Mondol et al. [72] \\
\hline Verrucarin Z & Antifungal activity & Isaka et al. [50] \\
\hline Epiroridin E & Antimalarial agent & Carter et al. [73] \\
\hline Epiroridin acid & Inhibits ovarian cancer & Mondol et al. [72] \\
\hline
\end{tabular}

\section{Conclusion}

Every study conducted on Myrothecium resulted in discovery of new metabolites or pointing to a possible application, which made Myrothecium species potential source of pharmaceuticals and attracted attention for further investigations of their medical properties. On the other hand, those fungi have various applications in large scale production of industrial enzymes, antibiotics, bioherbicides, and insecticides. Challenges of mycotoxins production by those fungi can be overcome as previously mentioned besides via conducting more studies.

\section{References}

1. Baute MA, Deffieux G, Baute R, Neveu A (1978) New antibiotics from the fungus Epicoccum nigrum. I. Fermentation, isolation and antibacterial properties. Journal of Antibiotics 31(11): 1099-1101.

2. Wang YU, Guo LD, Hyde KD (2005) Taxonomic placement of sterile morphotypes of endophytic fungi from Pinus tabulaeformis (Pinaceae) in northeast China based on rDNA sequences. Fungal Diversity 20: 235260.

3. Brooks FT (1945) Notes on the pathogenicity of Myrothecium roridum tode ex fr. Transactions of the British Mycological Society 27(3-4): 155157.

4. Domsh KH GW, Anderson TH (2007) Compendium of soil fungi. IHWVerlag, Eching, Germany, pp. 672.

5. Quezado Duval AM, Henz GP, Paz Lima ML, Medeirosss AR, Miranda BE, et al. (2010) New hosts of Myrothecium spp. in Brazil and a preliminary in vitro assay of fungicides. Brazilian Journal of Microbiology 41(1): 246-252.

6. Cunfer BM (1969) Studies on the biology of Myrothecium roridum and M. verrucaria pathogenic on red clover. Phytopathology 59: 1306-1309.

7. Ellis MB, Ellis JP (1985) Microfungi on land plants. An identification handbook. Macmillan Publishing, New York, USA.
8. Watanabe T (1993) Pictorial Atlas of soil and seed fungi (No. 632.4 W29p Ej.1). CRC Press, Florida, United States.

9. Ahrazem O, Gómez Miranda B, Prieto A, Bernabé M, Leal JA (2000) Heterogeneity of the genus Myrothecium as revealed by cell wall polysaccharides. Archives of microbiology 173(4): 296-302.

10. Anderson KI, Hallett SG (2004) Herbicidal spectrum and activity of Myrothecium verrucaria. Weed Science 52(4): 623-627.

11. Seifert K, Morgan Jones G, Gams W, Kendrick B (2011) The Genera of Hyphomycetes CBS-KNAW Fungal Biodiversity Centre Utrecht. The Netherlands, pp. 1-997.

12. Hsu YH, Nakagawa M, Hirota A, Shima S, Nakayama M (1988) Structure of myrocin B, a new diterpene antibiotic produced by Myrothecium verrucaria. Agricultural and biological chemistry 52(5): 1305-1307.

13. Hoagland RE, Weaver MA, Boyette CD (2007) Myrothecium verrucaria Fungus: A Bioherbicide and Strategies to Reduce Its Non-Target Risks. Allelopathy Journal 19(1): 179-192.

14. Bräse S, Encinas A, Keck J, Nising CF (2009) Chemistry and biology of mycotoxins and related fungal metabolites. Chemical reviews 109(9): 3903-3990.

15.Zou X, Niu S, Ren J, Li E, Liu X, et al. (2011) Verrucamides A-D, antibacterial cyclopeptides from Myrothecium verrucaria. Journal of natural products 74(5): 1111-1116.

16. Basnet B, Liu L, Chen B, Suleimen Y, Yu H, et al. (2019) Four New Cytotoxic Arborinane-Type Triterpenes from the Endolichenic Fungus Myrothecium inundatum. Planta medica.

17. Ueno Y (1983) General toxicology. Trichothecenes-Chemical, Biological and Toxicological Aspects, pp. 135-146.

18. Moss MO (1996) Centenary review: mycotoxins. Mycological Research $100(5): 513-523$

19. Yang CS, Johanning E (1997) Airborne fungi and mycotoxins. In: Hurst CJ, Knudsen GR, McInerney MJ, Stetzenbach LD, Walter MV (Eds.), Manual of Environmental Microbiology. ASM Press, Washington DC, USA, pp. 651-600. 
20. Wagenaar MM, Clardy J (2001) Two new roridins isolated from Myrothecium sp. Journal of Antibiotics 54(6): 517.

21. Kobayashi H, Namikoshi M, Yoshimoto T, Yokochi T (1996) A screening method for antimitotic and antifungal substances using conidia of Pyricularia oryzae, modification and application tropical marine fungi. Journal of Antibiotics 49(9): 873.

22. Podieiablonskaia EV, Kolomytseva MP, Myasoedova NM, Baskunov BP, Chernykh AM, et al. (2017) Myrothecium verrucaria F-3851, a producer of laccases transforming phenolic compounds at neutral and alkaline conditions. Microbiology 86(3): 370-376.

23. Mendonsa ES, Vartak PH, Rao JU, Deshpande MV (1996) An enzyme from Myrothecium verrucaria that degrades insect cuticles for biocontrol of Aedes aegypti mosquito. Biotechnology Letters 18 (4): 373-376.

24. Chavan SB, Vidhate RP, Kallure GS, Dandawate NL, Khire JM, et al. (2017) Stability studies of cuticle degrading and mycolytic enzymes of Myrothecium verrucaria for control of insect pests and fungal phytopathogens. 404-412.

25. Lamovšek J, Urek G, Trdan S (2013) Biological control of root-knot nematodes (Meloidogyne spp.): microbes against the pests. Acta Agriculturae Slovenica 101(2): 263-275.

26. Dong H, Zhou XG, Wang J, Xu Y, Lu P (2015) Myrothecium verrucaria strain X-16, a novel parasitic fungus to Meloidogyne hapla. Biological Control 83: 7-12.

27. Douglas Boyette C, Hoagland RE, Abbas HK (2007) Evaluation of the bioherbicide Myrothecium verrucaria for weed control in tomato (Lycopersicon esculentum). Biocontrol science and technology 17(2): 171-178.

28. Walker HL, Tilley AM (1997) Evaluation of an isolate of Myrothecium verrucaria from sicklepod (Senna obtusifolia) as a potential mycoherbicide agent. Biological Control 10(2): 104-112.

29. Yang SM (1994) Control of Carduus acanthoides with Myrothecium verrucaria in the greenhouse in the absence of dew. Phytopathology 84: 1136.

30. Yang SM, Jong SC (1995) Host range determination of Myrothecium verrucaria isolated from leafy spurge. Plant Dis 79(10): 994-997.

31. Boyette CD, Walker HL, Abbas HK (1999) Biological control of kudzu (Pueraria montana) with an endemic fungal pathogen. Proc South Weed Sci Soc 52: 237.

32. Abbas HK, Tak H, Boyette CD, Shier WT, Jarvis BB (2001) Macrocyclic trichothecenes are undetectable in kudzu (Pueraria montana) plants treated with a high-producing isolate of Myrothecium verrucaria. Phytochemistry 58(2): 269-276.

33. Boyette CD, Walker HL, Abbas HK (2002) Biological control of kudzu (Pueraria lobata) with an isolate of Myrothecium verrucaria. Biocontrol Science and Technology 11(1): 677684.

34. Hoagland RE, Mc Callister Boyette CD, Weaver MA, Beecham RV (2011) Effects of Myrothecium verrucaria on Morningglory (Ipomoea) Species. Allelopathy Journal 27: 151-162.

35. Bean GA, Jarvis BB, Aboul Nasr MB (1992) A biological assay for the detection of Myrothecium spp. produced macrocyclic trichothecenes. Mycopathologia 119(3): 175-180.

36. Weaver MA, Hoagland RE, Boyette CD, Zablotowicz RM (2009) Macrocyclic Trichothecene Production and Sporulation by a Biological Control Strain of Myrothecium verrucaria Is Regulated by Cultural Conditions. World Mycotoxin Journal 2(1): 35-43.

37. Boyette CD, Weaver MA, Hoagland RE, Stetina KC (2008) Submerged Culture of a Mycelial Formulation of a Bioherbicidal Strain of Myrothecium verrucaria with Mitigated Mycotoxin Production. World Journal of Microbiology and Biotechnology 24(11): 2721- 2726.

38. Shimizu A, Kwon JH, Sakurai T, Satoh T, Sakurai N, et al. (1999) Myrothecium verrucaria BOD and its mutants for potential copper ligands. Biochemistry 38(10): 3034-3042.
39. Sulistyaningdyah WT, Ogawa J, Tanaka H, Maeda C, Shimizu S (2004) Characterization of alkaliphilic laccase activity in the culture supernatant of Myrothecium verrucaria 24G-4 in comparison with bilirubin oxidase. FEMS Microbiology Letters 230(2): 209-214.

40. Han X, Zhao M, Lu L, Liu Y (2012) Purification, characterization and decolorization of bilirubin oxidase from Myrothecium verrucaria 3.2190. Fungal biology 116(8): 863-871.

41. Zhang X, Liu Y, Yan K, Wu H (2007) Decolorization of anthraquinone-type dye by bilirubin oxidase-producing nonligninolytic fungus Myrothecium $s p$. IMER1. Journal of bioscience and bioengineering 104(2): 104-110.

42. Mano N (2012) Features and applications of bilirubin oxidases. Applied microbiology and biotechnology 96(2): 301-307.

43. Pita M, Gutierrez Sanchez C, Toscano MD, Shleev S, De Lacey A (2013) Oxygen biosensor based on bilirubin oxidase immobilized on a nanostructured gold electrode. Bio electrochemistry 94: 69-74.

44. Arugula M, Pinchon E, Pant K, Singhal S (2018) Enhancement of Electrochemical Performance of Bilirubin Oxidase Modified Gas Diffusion Biocathode By Porphyrin Precursor. In Meeting Abstracts. The Electrochemical Society 8: 1-9.

45. Muhsin TM, Khalaf KT, Al Duboon AH (2012) Antimicrobial Bioactive Compound Isolated from the Fungus Myrothecium verrucaria. Journal of Biologically Active Products from Nature 2(3): 151-157.

46. Pervez MR, Musaddiq M, Thakare PV (2012) In vitro antimicrobial studies of isolated Myrothecium spp mrp001 against human pathogens. International Journal of Basic and Applied Medical Sciences 2(3): 228236.

47. Ruma K, Sunil K, Prakash HS (2014) Bioactive potential of endophytic Myrothecium sp. isolate M1-CA-102, associated with Calophyllum apetalum. Pharmaceutical biology 52(6): 665-676.

48. Fu Y, Wu P, Xue J, Wei X (2014) Cytotoxic and antibacterial quinone sesquiterpenes from a Myrothecium fungus. Journal of natural products 77(8): 1791-1799.

49. Gülay T, Grossmann F (1994) Antagonistic activity of five Myrothecium species against fungi and bacteria in vitro. Journal of Phytopathology 140(2): 97-113.

50. Kobayashi M, Sato I, Abe F, Nitta K, Hashimoto M, et al. (2004) FR227244 a Novel Antifungal Antibiotic from Myrothecium cinctum No. 002: II. Biological Properties and Mode of Action. The Journal of antibiotics 57(12): 788-796.

51. Isaka M, Punya J, Lertwerawat Y, Tanticharoen M, Thebtaranonth Y (1999) Antimalarial activity of macrocyclic trichothecenes isolated from the Fungus Myrothecium verrucaria. Journal of natural products 62(2): 329-331.

52. Nakagawa M, Hsu YH, Hirota A, Shima S, Nakayama M (1989) Myrocin C, a new diterpene antitumor antibiotic from Myrothecium verrucaria. The Journal of antibiotics 42(2): 218-222.

53. Murakami R, Kobayashi T, Takahashi K (2005) Myrothecium leaf spot of mulberry caused by Myrothecium verrucaria. Journal of General Plant Pathology 71(2): 153-155.

54. Ye W, Chen Y, Li H, Zhang W, Liu H, et al. (2016) Two trichothecene mycotoxins from Myrothecium roridum induce apoptosis of HepG-2 cells via caspase activation and disruption of mitochondrial membrane potential. Molecules 21(6): 781

55. Souza Motta CM, Cavalcanti MAD, Fernandes MJD, Lima DMM, Nascimento JP, et al. (2003) Identification and characterization of filamentous fungi isolated from the sunflower (Helianthus annus L.) rhizosphere according to their capacity to hydrolyse inulin. Brazilian Journal of Microbiology 34(3): 273-280.

56. Costa Isabella PM, Maria Auxiliadora Q Cavalcanti Maria José S Fernandes, Débora MM Lima (2006) Hyphomycetes from soil of an area affected by copper mining activities in the State of Bahia, Brazil. Brazilian Journal of Microbiology 37(3): 290-295. 
57. Bilal Y, Asad UR, Muhammad S, Saeed A, Arshad H, et al. (2018) Risk of Myrothecium Roridum Leaf Spot in Local Cucurbitaceous Crops of Pakistan. JOJ Hortic Arboric 2(1): 555577.

58. Han KS, Choi SK, Kim HH, Lee SC, Park JH, et al. (2014) First report of Myrothecium roridum causing leaf and stem rot disease on Peperomia quadrangularis in Korea. Mycobiology 42(2): 203-205.

59. Schieber E, Zentmyer GA (1969) Myrothecium/stem necrosis and leaf spot: important Coffee disease in Guatemala. Plan Disease Report (Estados Unidos) 52(2): 115-117.

60. Neergaard P (1979) Seed pathology. The Macmillan Press, England, pp. 839.

61. Du HM, Pu GQ, Mao JP, Fan JN, Wei SJ, et al. (1988) Isolation, identification and biological characters of the pathogen, Myrothecium roridum Tode ex Fr. caused a tar leaf spot disease 77 of mulberry (in Chinese). Plant Protection Journal 3: 43-47.

62. Lizhe L (1989) Myrothecium species on chilli seeds, their pathogenicity and response to temperature and light (in Chinese). Acta Agricultuae Boreali-Sinica 4 (3): 94-98.

63. Norman DJ, Ali S (2013) Ornamental dicus diseases: identification and control in commercial greenhouse operations. University of Florida 308: $1-7$.

64. Patidar P (2016) Studies on the Myrothecium leaf blight of Cotton incited by Myrothecium roridum Tode ex. Fries (Doctoral dissertation, RVSKVV, Gwalior (MP).

65. Leath KT, Kendall WA (1983) Myrothecium roridum and M. verrucaria pathogenic to roots of red clover and alfalfa. Plant disease 67(10): 11541155.

66. Narain U, Koul AK (1984) Myrothecium leaf spot of sunflower. Plant protection, bulletin 32(4): 146

\section{ISSN: 2574-1241}

DOI: 10.26717/BJSTR.2019.16.002869

Ghoson Mosbah Daba. Biomed J Sci \& Tech Res

This work is licensed under Creative Commons Attribution 4.0 License

Submission Link: https://biomedres.us/submit-manuscript.php
67. Nguyen TH, Mathur SB, Neergaard P (1973) Seed-borne species of Myrothecium and their pathogenic potential. Transactions of the British Mycological Society 61(2): 347-IN416.

68. Jordan B, Culbreath AK, Brock J, Dutta B (2018) First Report of Myrothecium Leaf Spot Caused by Myrothecium roridum on Pepper in the United States. Plant Disease 102(1): 246.

69. Chen Y, Ran SF, Dai DQ, Wang Y, Hyde KD, et al. (2016) Mycosphere Essays 2, Myrothecium. Mycosphere 7: 64-80.

70. Radostits OM, Gay CC, Hinchcliff KW, Constable PD (2006) Veterinary Medicine E-Book: A textbook of the diseases of cattle, horses, sheep, pigs and goats. Elsevier Health Sciences.

71. Nguyen LT, Jang JY, Kim TY, Yu NH, Park AR, et al. (2018) Nematicidal activity of verrucarin A and roridin A isolated from Myrothecium verrucaria against Meloidogyne incognita. Pesticide biochemistry and physiology 148: 133-143.

72. Liu Y, Gao X, Deeb D, Zhang Y, Shaw J, et al. (2016b) Mycotoxin verrucarin A inhibits proliferation and induces apoptosis in prostate cancer cells by inhibiting prosurvival Akt/NF- $\mathrm{B} / \mathrm{mTOR}$ signaling. Journal of experimental therapeutics \& oncology 11(4): 251-260.

73. Mondol MA, Surovy MZ, Islam MT, Schüffler A, Laatsch H (2015) Macrocyclic trichothecenes from Myrothecium roridum strain M10 with motility inhibitory and zoosporicidal activities against Phytophthora nicotianae. Journal of agricultural and food chemistry 63(40): $8777-$ 8786

74. Carter K, Rameshwar P, Ratajczak MZ, Kakar SS (2017) Verrucarin J inhibits ovarian cancer and targets cancer stem cells. Oncotarget 8(54): 92743.

75. Liu HX, Liu WZ, Chen YC, Sun ZH, Tan YZ, et al. (2016a) Cytotoxic trichothecene macrolides from the endophyte fungus Myrothecium roridum. Journal of Asian natural products research 18(7): 684-689.

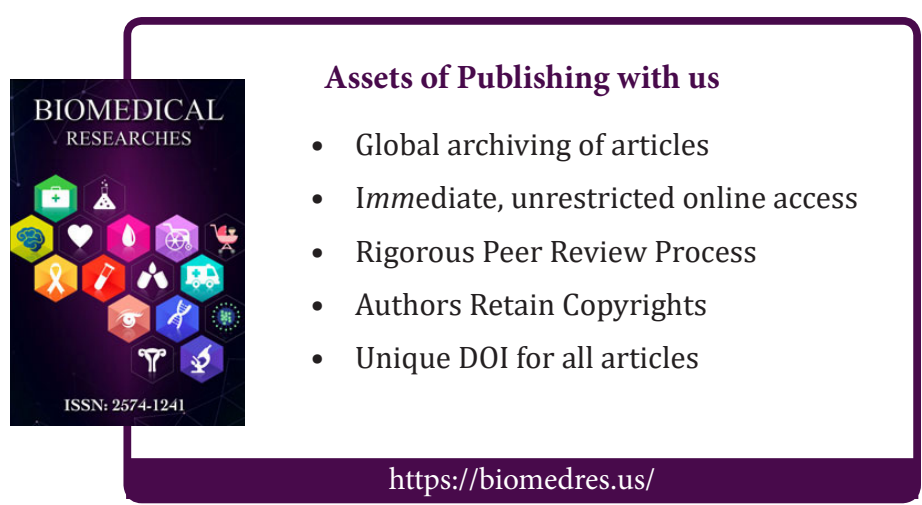

